\title{
Production of Alkaline Protease from Acetic Acid ${ }^{\dagger}$
}

\author{
Shigeho IkedA, Sadanobu Tobe, Kunimori Niwa, \\ Ayaaki IsHIzAKI and Yoshio Hirose \\ Central Research Laboratories of Ajinomoto Co., Inc., Kawasaki, Japan \\ Received March 15, 1974
}

\begin{abstract}
The use of acetic acid as a carbon source in alkaline protease fermentation was examined. Acetic acid was a good carbon source and yielded a great deal of alkaline protease.

Acetic acid has advantages over ordinary carbon sources such as starch and glucose in that it can be supplied to culturing liquid as much as needed to perform the fermentation efficiently, that it has a function to control the $\mathrm{pH}$ of culturing liquid at a constant level and that it was obtained at lower price.
\end{abstract}

The maximum proteolytic activity attained was $1.6 \times 10^{4} \mathrm{units} / \mathrm{ml}(11.4 \mathrm{mg}$-enzyme/ml).

There have been many works about alkaline proteases, but much attention has been paid to its enzymatic and physicochemical properties. ${ }^{1 \sim 3)}$ As proteases became abundantly used in many fields, there occurred the need of its production on a large scale at a low price. In order to establish the economical process for the production of alkaline protease, the selection of carbon sources was very important.

Usually, starch, ${ }^{4,51}$ glucose, ${ }^{61}$ dextrin ${ }^{71}$ and sucrose $^{8)}$ have been used as carbon sources, but as yet it has not been established which is the most suitable substrate for the production. The use of $n$-paraffin was investigated by Nakao, ${ }^{9}$ ) and it was found that a large amount of alkaline protease was produced from it by Fusarium sp.

Recently, acetic acid was brought to the fore as a new carbon source, because it can be obtained in a large quantity at a low price. Acetic acid was already used in amino acid fermentations such as L-glutamic acid ${ }^{10 \sim 14)}$ and L-lysine ${ }^{15)}$ and also used in yeast cell production. ${ }^{16)}$ The authers tried to use acetic acid as a carbon source to produce alkaline protease efficiently.

Bacillus subtilis AJ 3266 was mainly used in this study. This bacterium produces alkaline

${ }^{\dagger}$ This paper was presented at the Annual Meeting of Agricultural Chemical Society of Japan held in Tokyo, Japan, on 1st April, 1973. protease of the following characteristics: Optimum $\mathrm{pH}, 10.5$; Stable $\mathrm{pH}, 6.0 \sim 10.0$; Optimum temperature, $60^{\circ} \mathrm{C}$; Isoelectric point, pH 6.4; Stable with $\mathrm{Ca}^{2+}$; Completely inactivated with DFP but still active with EDTA; Molecular weight, 30,000 estimated by gelfiltration; Specific activity, 1,400 units $/ \mathrm{mg}$ enzyme at $\mathrm{pH} 9.5$. These properties suggested that this protease is similar to subtilisin $\mathbf{B P N}^{\prime}{ }^{2}$ )

\section{MATERIALS AND METHODS}

Fermentation. Fermentation was carried out in jar fermentors containing medium of 30 liters under the aeration of $1 / 2 \mathrm{v} / \mathrm{v} / \mathrm{M}$ and agitation of $400 \mathrm{rpm}$ at $34 \mathrm{C}$ for $2 \sim 3$ days. Shaking flasks were also used in some experiments. The culturing conditions were as follows; $20 \mathrm{ml}$ of medium in $500 \mathrm{ml}$ shaking flask; $7 \mathrm{~cm}$ stroke and 140 oscillations per minute; $34^{\circ} \mathrm{C}$. Composition of the medium is given in Table I.

Analysis. Proteolytic activity was assayed by the Hagiwara's modification ${ }^{17)}$ of Anson's method empolying milk casein as a substrate. One unit of proteolytic activity was defined as the enzyme activity which liberate $1 \mu \mathrm{g}$ of tyrosine per minute at $37^{\circ} \mathrm{C}$ and pH 9.5.

Bacterial growth was expressed in optical density $(-\log T)$ at $562 \mathrm{~nm}$ of the cultured broth diluted 26 fold with water.

\section{RESULTS}

1. Influence of glucose and starch concentration on protease production

Figure 1 shows the time courses of alkaline 


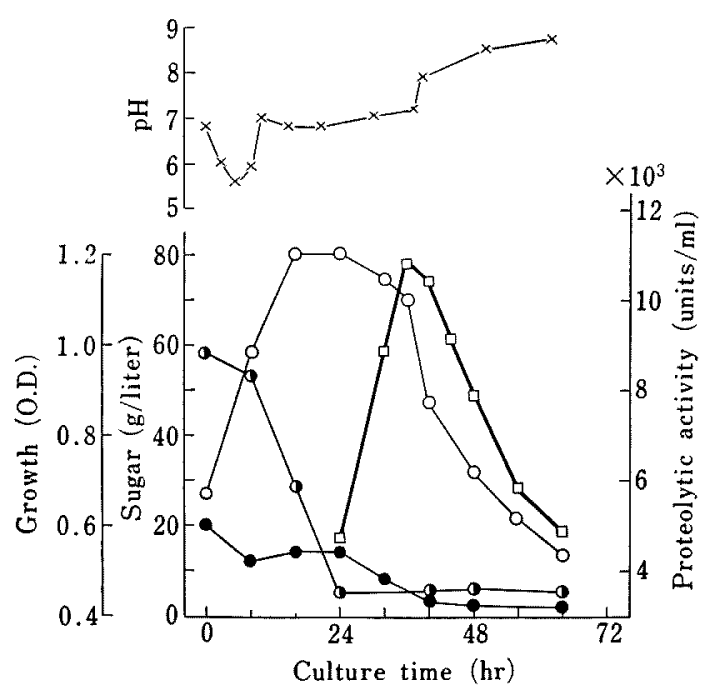

FIG. 1. Time Courses of Protease Fermentation without $\mathrm{pH}$ Control.

$\times, \mathrm{pH} ; \mathrm{O}$, growth; $\square$, proteolytic activity; $\mathbf{O}$, starch;

, glucose.

protease fermentation, where starch and glucose were used as substrates and $\mathrm{pH}$ was not controlled at a constant level. As the assimilation of carbon sources progressed, growth of bacteria and the production of protease occurred. But at $36 \mathrm{hr}$ of cultivation, protease production suddenly stopped and proteolytic activity began to decrease on the contrary. This was the point where carbon sources were exhausted and $\mathrm{pH}$ began to rise sharply. This data suggested that the control of $\mathrm{pH}$ and the replenishment of carbon sources were important to increase the protease production.

So, the $\mathrm{pH}$ was tried to be maintained at 6.7 with sulfuric acid and sodium hydroxide (Fig. 2). The abrupt diminution of proteolytic activity was prevented, but protease production did not increase.

Then, the concentration of carbon sources was tried to increase. It is well known that starch solution gets a high viscosity after heat treatment. Table II shows the relation between the concentration of the starch used in the experiments and the viscosity. The logarithm of viscosity increased in proportion to the starch concentration. It seemed to be difficult to increase the starch concentration above

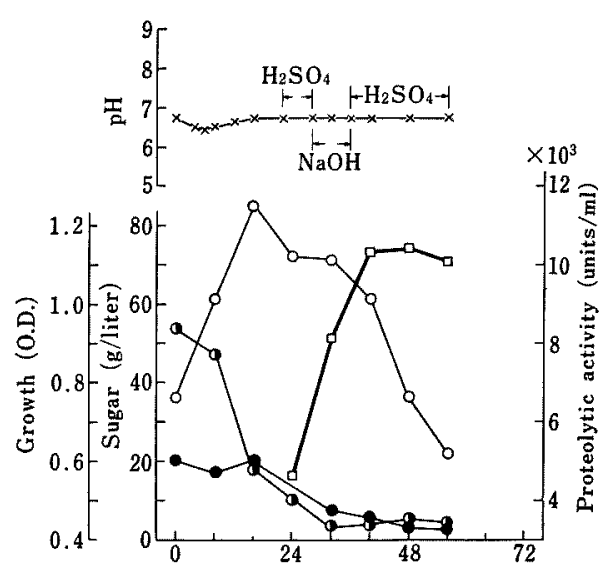

FIG. 2. Time Courses of Protease Fermentation with $\mathrm{pH}$ Control by Sodium Hydroxide and Sulfuric Acid.

$\times, \mathrm{pH} ; \mathrm{O}$, growth; $\square$, proteolytic acitivity; $\mathbf{m}$, starch; , glucose.

Table I. Composition of the Medium

\begin{tabular}{lc}
\multicolumn{1}{c}{ Carbon source } & Variable \\
\hline Casein & $15 \mathrm{~g} /$ liter \\
"Ajipron $60 "$ a) & $20 \mathrm{~g} /$ liter \\
$\mathrm{KH}_{2} \mathrm{PO}_{4}$ & $2.5 \mathrm{~g} /$ liter \\
$\mathrm{MgSO}_{4} \cdot 7 \mathrm{H}_{2} \mathrm{O}$ & $0.2 \mathrm{~g} /$ liter \\
$\mathrm{CaCl}_{2} \cdot 2 \mathrm{H}_{2} \mathrm{O}$ & $2 \mathrm{~g} /$ liter \\
"Mieki" $b_{1}$ & $20 \mathrm{ml} /$ liter \\
$\mathrm{pH}$ & 7.0 \\
\hline
\end{tabular}

a) Hot water extracts of soy bean meal, containing 60 grams of protein per $100 \mathrm{~g}$.

b) Aqueous solution of amino acids prepared from $\mathrm{HCl}$-hydrolyzate of soy bean meal, containing 3 grams of nitrogen per liter.

TABLE II. VISCOSITY OF THIN Bolling STARCH

\begin{tabular}{cc}
\hline $\begin{array}{c}\text { Thin boiling starch } \\
\text { (g/liter) }\end{array}$ & $\begin{array}{c}\text { Viscosity } \\
\text { (C.P.) }\end{array}$ \\
\hline 0 & 1 \\
100 & 11 \\
200 & 140 \\
300 & 2,250 \\
\hline
\end{tabular}

$100 \mathrm{~g} /$ liter, judging from the viscosity of the medium. Accordingly, the influence of the starch concentration from zero to $90 \mathrm{~g} /$ liter on protease production was examined. As the rise of glucose concentration did not bring about the increase of viscosity, the replacement 


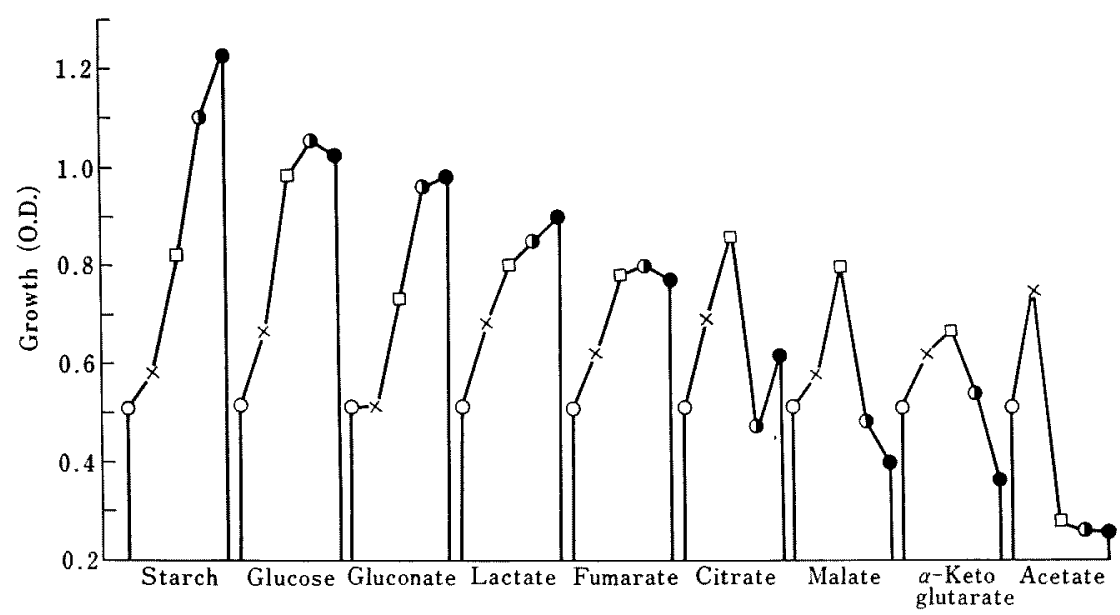

FIG. 3. Assimilation of Substrates by Bacillus subtilis AJ 3266.

O, blank; $\times, 10 ; \square, 30 ; \mathbf{O}, 50 ; \bullet, 70$ (g/liter).

of starch by glucose was also examined (Table III).

Table III. Influence of Starch and Glucose on Protease Production

Shaking culture, $34^{\circ} \mathrm{C}, 48 \mathrm{hr}$.

\begin{tabular}{ccc}
\hline $\begin{array}{c}\text { Starch } \\
(\mathrm{g} / \text { liter })\end{array}$ & $\begin{array}{c}\text { Glucose } \\
\text { (g/liter) }\end{array}$ & $\begin{array}{c}\text { Proteolytic activity } \\
\text { (units/ml) }\end{array}$ \\
\hline 50 & 0 & 9,300 \\
30 & 20 & 6,100 \\
0 & 50 & 5,000 \\
70 & 0 & 9,730 \\
50 & 20 & 9,400 \\
35 & 35 & 9,530 \\
20 & 50 & 8,900 \\
0 & 70 & 7,830 \\
90 & 0 & 9,860 \\
50 & 40 & 7,530 \\
0 & 90 & 5,900 \\
\hline
\end{tabular}

Proteolytic activity increased little by the rise of starch concentration. The replacement of starch by glucose resulted in the decrease in proteolytic activity. In this way, the trial to increase the concentration of carbon sources by starch and glucose was unsuccessful.

\section{Screening of new carbon sources}

Several kinds of carbon sources were examined to find out other suitable substrates than starch and glucose. Figure 3 shows the growth of Bacillus subtilis AJ 3266 with each substrate at individual concentration. This bacterium utilized many kinds of substrates. Among them, acetic acid was the most interesting from the view point of economy and its $\mathrm{pH}$ controlling function.

Figure 4 shows the time course of fermenta-

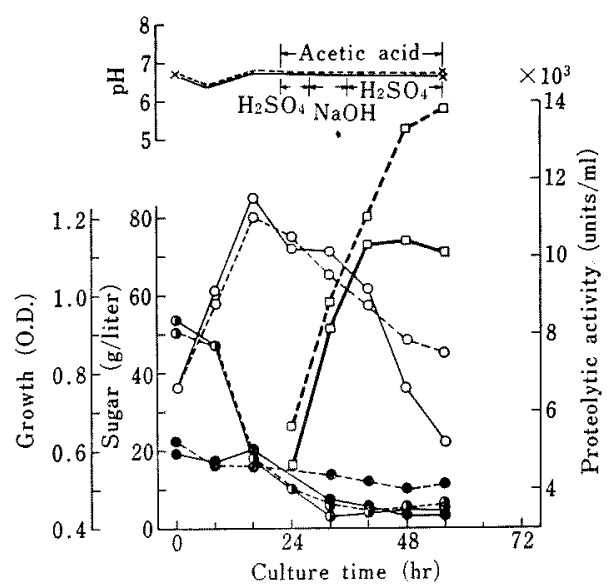

FIG. 4. Influence of $\mathrm{pH}$ Controlling Reagents on Protease Formation.

$\times, \mathrm{pH} ; \mathrm{O}$, growth; $\square$, proteolytic acitvity; $\boldsymbol{O}$, starch; - glucose; - $\mathrm{pH}$ was controlled by sodium hydroxide and sulfuric acid; ---, pH was controlled by acetic acid.

tion where acetic acid was supplied when the $\mathrm{pH}$ rose beyond 6.7. When acetic acid was used as $\mathrm{pH}$ controlling reagent, proteolytic ac- 
Table IV. Replacement of Starch and Glucose by Acetic Acid

Acetic acid was supplied automatically when the $\mathrm{pH}$ rose beyond 6.7. Therefore, substrate supply and $\mathrm{pH}$ control were performed simultaneously with acetic acid.

\begin{tabular}{ccccc}
\hline $\begin{array}{c}\text { Starch } \\
\text { (g/liter) }\end{array}$ & $\begin{array}{c}\text { Initial C-source } \\
\text { Glucose } \\
\text { (g/liter) }\end{array}$ & $\begin{array}{c}\text { Added } \\
\text { acetate } \\
\text { (g/liter) }\end{array}$ & $\begin{array}{c}\text { Total } \\
\text { C-source } \\
\text { (g/liter) }\end{array}$ & $\begin{array}{c}\text { Proteolytic } \\
\text { activity } \\
\text { (units/ml) }\end{array}$ \\
\hline 75 & 20 & 56 & 155 & 13,400 \\
50 & 20 & 66 & 140 & 14,800 \\
25 & 20 & 84 & 135 & 15,600 \\
0 & 20 & 103 & 130 & 15,400 \\
0 & 0 & 139 & 139 & 15,980 \\
\hline
\end{tabular}

tivity reached $1.4 \times 10^{4}$ units $/ \mathrm{ml}$, while it was $10^{4}$ units/ml by the use of sodium hydroxide and sulfuric acid as $\mathrm{pH}$ controlling reagents. This difference suggested the use of acetic acid as a substrate.

Replacement of starch and glucose by acetic acid was examined to know clearly the function of acetic acid as substrate (Table IV). As the concentration of starch and glucose decreased, the consumption of acetic acid increased, and the total amount of carbon sources did not differ so much. Proteolytic activity rose as the part of acetic acid increased in total carbon sources. Thus, acetic acid was found to be a better carbon source than starch and glucose. The best result was obtained when only acetic acid was used as the.carbon source.

\section{Conditions of protease production from acetic acid}

Figure 5 shows the influence of culturing $\mathrm{pH}$ on growth, protease formation, spore formation and acetic acid consumption. Although, growth was not affected, protease production was greatly influenced by culturing $\mathrm{pH}$. The optimum $\mathrm{pH}$ for protease production was 7.0. Culturing $\mathrm{pH}$ had also a great influence on spore formation and acetic acid consumption. With the rise of culturing $\mathrm{pH}$, spore formation increased and acetic acid consumption decreased.

Acetic acid was known to exert harmful influences on microorganisms at its high concentration. Consequently, it was very important to know the optimum level of acetic acid concentration in culture liquid. Figure 6 shows

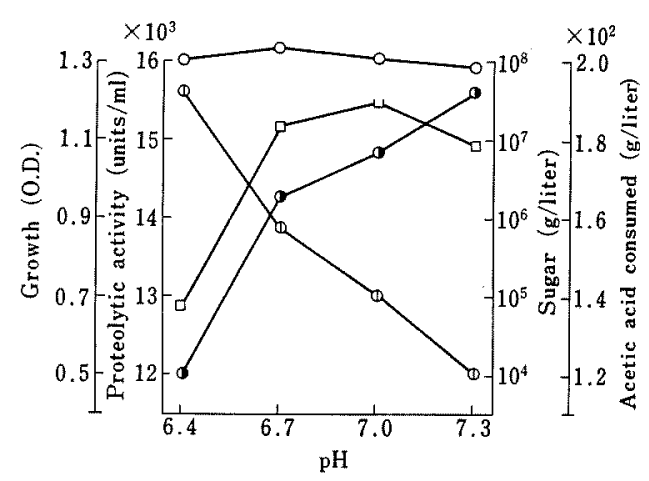

FIG. 5. Effect of $\mathrm{pH}$ on Protease Fermentation. $O$, growth; $\square$, proteolytic activity; $\mathbf{O}$, spore; (D), acetic acid consumed.

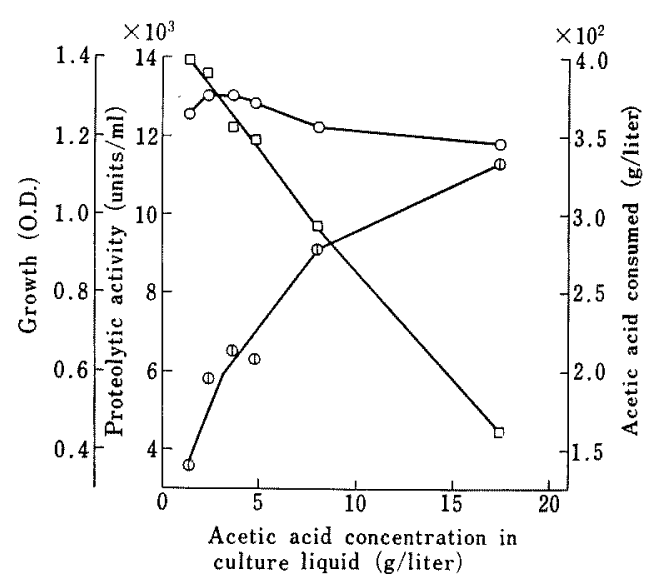

FIG. 6. Effect of Acetic Acid Concentration in Culture Liquid on Protease Fermentation.

$\bigcirc$, growth; $(1)$, acetic acid consumed; $\square$, proteolytic activity.

the results. With the rise of acetic acid concentration in culture liquid, protease formation decreased in a linear fashion, but conversely 
Table V. Influence of Casein and Acetic Acid on Protease Production

\begin{tabular}{ccccccc}
\hline $\begin{array}{c}\text { Casein } \\
(\mathrm{g} / \text { liter })\end{array}$ & $\begin{array}{c}\text { Total-N } \\
(\mathrm{g} / \text { liter })\end{array}$ & $\begin{array}{c}\text { Acetate } \\
(\mathrm{g} / \text { liter })\end{array}$ & $\begin{array}{c}\text { Proteolytic } \\
\text { activity } \\
\text { (units/ml) }\end{array}$ & $\begin{array}{c}\text { Protease } \\
(\mathrm{g} / \text { liter })\end{array}$ & $\begin{array}{c}\text { Protease-N } \\
\text { Total-N }\end{array}$ & $\begin{array}{c}\text { Acetate } \\
\text { Protease }\end{array}$ \\
\hline 15 & 2.76 & 124 & 8,000 & 5.71 & 0.33 & 21.7 \\
30 & 5.04 & 184 & 14,100 & 10.1 & 0.32 & 18.2 \\
45 & 7.32 & 222 & 19,100 & 13.6 & 0.30 & 16.3 \\
60 & 9.60 & 295 & 19,800 & 14.1 & 0.24 & 20.9 \\
\hline
\end{tabular}

Protease $1 \mathrm{~g}=1.4 \times 10^{6}$ units.

acetic acid consumption increased. Under a high concentration of acetic acid, the bacteria seemed to waste acetic acid in a view point of protease production. In order to produce protease efficiently, it was necessary to maintain the acetic acid concentration in culture liquid as low as possible.

\section{Influence of casein concentration}

Figure 7 shows the time courses of fermentation where casein concentration varied from 15 to $60 \mathrm{~g} /$ liter. With the increase of casein, which was a nitrogen source in this fermentation, growth and protease formation increased. It was very interesting that acetic acid consumption also increased along with the increase of casein.

Table $\mathrm{V}$ shows the summary of this experiment. Total nitrogen in the media changed with casein concentration. Proteolytic activity is shown in modified numerical values, accounting the increase of liquid volume by the supply of acetic acid. This protease was crystallized and measured its proteolytic activity. One gram of this protease had $1.4 \times 10^{6}$ units of proteolytic activity. Proteolytic activity in culture liquid was converted into the concentration of protease and it is shown in the 5th column of Table V. Protease concentration reached as much as $14 \mathrm{~g} /$ liter. Conversion ratio from medium component to protease on the bases of nitrogen is shown in the 6 th column. The ratio was almost constantly 0.3 within the casein concentrations from 15 to $45 \mathrm{~g} /$ liter. This shows that carbon source was not the limiting factor, that is to say, acetic acid was supplied as much as needed. The seventh column in Table $\mathrm{V}$

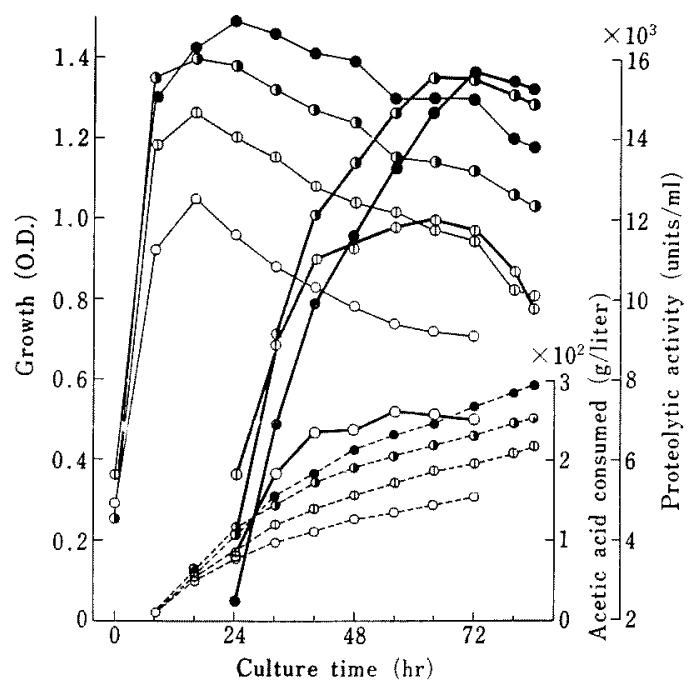

FIG. 7. Influence of Casein Concentration on Protease Fermentation.

0 , casein $15 \mathrm{~g} /$ liter; $x$, casein $30 \mathrm{~g} /$ liter; $\mathbf{T}$, casein 45 g/liter; - casein $60 \mathrm{~g} /$ liter; - - growth; -, proteolytic activity; ---, acetic acid consumed.

shows the amount of acetic acid consumed to produce 1 gram of protease. Although protease production changed from 5.7 to $14.1 \mathrm{~g} /$ liter, the ratio of acetic acid consumption to protease production did not change much.

\section{Utilization of acetic acid in other protease fermentations}

Bacillus sp. AJ 3368 produced another type of alkaline protease. ${ }^{18}$ In this fermentation, the use of acetic acid as carbon source and $\mathrm{pH}$ controlling reagent also lead to a remarkable increase in proteolytic activity; about ten-fold of protease was produced. Although the proteolytic activity decreased a little, fairly a great deal of protease was produced from acetic acid 
without the use of glucose.

Candida lipolytica AJ 4555 produced a different type of alkaline protease. ${ }^{19}$ The state of affairs was almost the same about this yeast (Table VI). About 2.5 fold of protease was produced with the use of acetic acid.

Table VI. Utilization of Acetic Acid in Other Protease Fermentation

\begin{tabular}{lcrrr}
\hline $\begin{array}{c}\text { Micro- } \\
\text { organism }\end{array}$ & $\begin{array}{c}\text { Starch } \\
\text { (g/liter) }\end{array}$ & $\begin{array}{c}\text { Glucose } \\
\text { (g/liter) }\end{array}$ & $\begin{array}{c}\text { Acetate } \\
\text { (g/liter) }\end{array}$ & $\begin{array}{c}\text { Proteolytic } \\
\text { activity } \\
\text { (units/ml) }\end{array}$ \\
\hline Bacillus & 50 & 20 & 0 & 2,590 \\
sp. & 50 & 20 & 92 & 21,700 \\
AJ 3368 & 0 & 0 & 201 & 14,660 \\
\hline Candida & 0 & 50 & 0 & 550 \\
lipolytica & 0 & 50 & 75 & 1,390 \\
AJ 4555 & 0 & 0 & 105 & 1,000 \\
\hline
\end{tabular}

\section{DISCUSSION}

The following conditions are necessary at least in order to perform protease fermentation efficiently;

(1) carbon sources and nitrogen sources should be consumed completely.

(2) the $\mathrm{pH}$ of the fermentation liquid should be controlled at a desired level.

In a usual protease fermentation, starch and glucose were used as carbon sources. In such case, it is very difficult to fulfil these conditions owing to the lack of suitable $\mathrm{pH}$ controlling reagents and the difficulty in the supplement of carbon source. The use of acetic acid solved these problems and lead to the efficient production of protease.

As carbon source itself, acetic acid was better than glucose or starch for Bacillus subtilis AJ 3266 as shown in Table IV. In case of other microorganisms described here, hyperproduction of protease was mainly due to the function of acetic acid as $\mathrm{pH}$ controlling reagent, and the best result was obtained when acetic acid was used with glucose or starch (Table VI).

\section{REFERENCES}

1) A. V. Güntleberg and M. Ottensen, Nature, 170, 802 (1952).

2) H. Matsubara, C. B. Kasper, D. M. Brown and E. L. Smith, J. Biol. Chem., 240, 1125 (1965).

3) L. Keay and P. W. Moser, Biochem. Biophys. Res. Comm., 43, 600 (1969).

4) D. Tsuru, H. Kira, T. Yamamoto and J. Fukumoto, Agr. Biol. Chem., 30, 1261 (1966).

5) J. Yagi, T. Yano, Y. Kubochi, S. Hattori, M. Ohashi, H. Sakai, K. Jomon and M. Ajisaka, J. Ferment. Technol., 50, 592 (1972).

6) K. Horikoshi, Agr. Biol. Chem., 35, 1407 (1971).

7) T. Yoshimoto, J. Fukumoto and D. Tsuru, Int. J. Protein Reseach, 3, 285 (1971).

8) M. Isono, K. Tomoda, K. Miyata, K. Maejima, H. Tachibana and K. Ito, Abstracts of Papers, the Annual Meeting of Agricultural Chemical Society of Japan, Fukuoka, April, 1970, p. 132.

9) Y. Nakao, M. Suzuki, K. Kuno and K. Maejima, Agr. Biol. Chem., 37, 1223 (1973).

10) T. Tsunoda, I. Shiio and K. Mitsugi, J. Gen. Appl. Microbiol., 7, 18 (1961).

11) T. Tsunoda, I. Shiio and K. Mitsugi, ibid., 7, 30 (1961).

12) K. Kimura, ibid., 10, 23 (1964).

13) T. Kanzaki, K. Kitano, Y. Sumino and H. Okazaki, Nippon Nôgeikagaku Kaishi, 46, 95 (1972).

14) K. Kitano, Y. Sugiyama and T. Kanzaki, J. Ferment. Technol., 50, 182 (1972).

15) K. Seto and T. Harada ibid., 47, 558 (1969).

16) K. Ogata, H. Nishikawa and M. Ohsugi, Agr. Biol. Chem., 33, 977 (1969).

17) B. Hagiwara, Ann. Rep. Sci. Work Osaka Univ., 2, 35 (1954).

18) S. Tobe, T. Takami, Y. Hirose and K. Mitsugi, in press, presented at the Meeting of Agricultural Chemical Society of Japan held in Tokyo, Japan, on 7th October, 1972.

19) K. Mitsugi, T. Takami, S. Tobe, M. Kimura, T. Nakase and K. Komagata, Agr. Biol. Chem., 35, 1633 (1971). 